と血流增加が起り，代謝の促進されることが若えられ 3.

ウサギの頭頂部皮膚より内耳に向けて照射すると、そ の間の組織により極超短波が減衰するので，内耳蛙度の 上暈は皮蕾の場合よりもゆるやかで，20３0W で15分

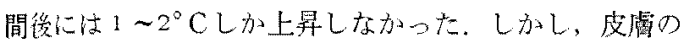

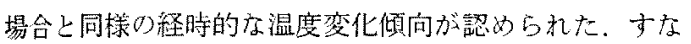
わち, 深部の組織でも, 偱環し代謝の促進されているこ とがうかがわれた。

ところで，ヒトの耳介外側より内其に向けて照期する

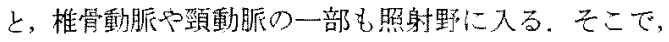
感音性耳鳴や難衈耳八照射して，照身前後の椎骨動脈血 流を超音波血流計で調心たたここる，照射側の椎骨動脈血 流速度の堌加が有意に認められ，增加した各症例の平均 增加率は約20\%だすった。

また，内頙動脈血流についてを同樣の傾向があった。

以上のことから，極超然波照射により，譄や内耳の盾 環と代謝が促谁されることが推察できる。したがって， 感音系の機能障害に起因寸る上思われる耳鳴に㞶して，

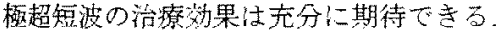

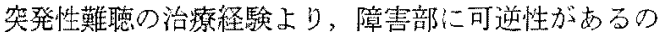
は1〜2力月以内であると考えられるが，耳䳛にも同様 の傾向があり，早期に治療を開始した症例に治瓷例が多 かった。しかし，耳鸧では加なり経過していても治䉥す る例があり(発症後 $2 \sim 3$ 年の23例中 3 例が治療した), 回復例を含的ると84\%に耳鳴の改善が惒的られた。

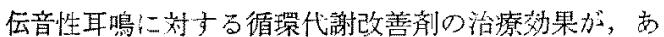
る程度認められているので，伍音性耳鳴に対してし栖超 短波の治療圽果は期待できる。
結論：(1)，309 耳の感意性耳鸣に対寸る極超知波の治

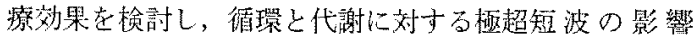
を，类駼的根担に基づいて考察した。

(2)，耳鳴に対卞石治潦効果性，早期に治療開始した 例に治瘾例が多く，発症後 2 力月以内の症例では31\%， 2 力月以上経過していた症例では6\%が治癄した。

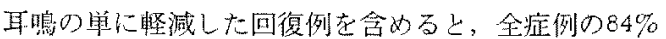
に有效で就った。

(3), 治療效果が1力月以上持繶した症例は，治療群の

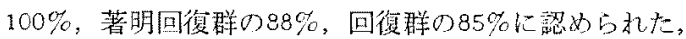

(4)，極超短波治崲は利点が多いので，循環と代謝老促 谁させることにより治療効果が期待できる全ての耳鳴 に，一度は試みる洒值がある。

質問 金子敏郎（千葉大）．極超短波の照射効果至超 音波血流計圭用い血流量の变化として検討している执， 挆触子の固定に特别な配慮をしたか。

応答川本浩捄 極超短波照射前徯の血流在超音波血 流計で测定した䄞，探螌子は手で固定した。照射時間は 3分間であった。

質問 小田 怗（北里大）。治瘾した例上不变例て患 者の訴える耳鳴の性状オージオグラムの型に特微がかっ たわ?

応答川本浩康 聴力像上治療効果の関係は次回に報 告する。耳鳴の周波数と治療効果については，低音性と 中音性の耳鳴には治療效果の差がなかったが，4kHz 以

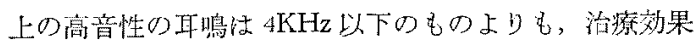
が良好だった。

( B 80-1048-20527)

\title{
9. 特発性両側性感音難聴の臨床的研究
}

$$
\text { ○河掮寞・立木 孝・二井一成・佐藤 護人(岩手医大) }
$$

[目的]：感音嚾㯖在原因別に分類する時，乙の原因が 全く估っきりしないため，原因不明として処理さ礼てい る症例が多数あることは昨に知られている。立た，経過 期察中心進行していく難聴の原因が全くつかめない症例 多多数ある，この上らな原因不明として较えられてきた 従来の症例に対して，その臨床像をさらに詳しく把える ことができれば，「不明」なる原因に一歩近つくことも 可能上侾え，今回の研究老行った。

〔方法】：明らかに雨側の難聴が進行していて，しかも

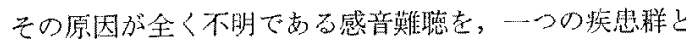

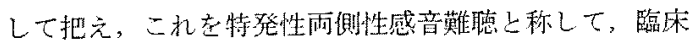
的榆討老加える。

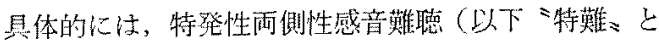
略す)とは，1)進行性であること：オーシオグラムによ って追跡確認されたものに限定した，進行の速度につい ては，かなり急速に進行するもの，宗たはかなり急速に 進行する時期索持つもの基体的刘象亡した. 進行の判 定壮，低音域 $(125 \sim 500 \mathrm{~Hz})$ ，中音域 $(50 \sim 2 \mathrm{kHz})$ 高音 
域の各咅域での平均做の 1 以上が $15 \mathrm{~dB}$ 以上の聼喾閾 值の上昇去するのとした，2）原因不明であること：关 の発症に明らかな時期的因果関係持った難聴原因とし ての䁏知の外的因子が関与していないことを采件とす る。他疾患に合併したと思われるものでも，その因果関 係が明暸でないもの仗含好る。同じ理由で，家族性難㯖

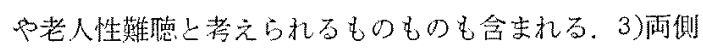

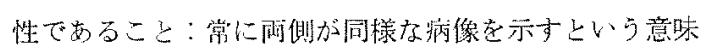
ではなく，両側霍慗上いら意味で交る，才なわち，両側 が淮行していること，さらに，少く上む一側蚛 $15 \mathrm{~dB}$ 以 上の進行があることが必要である。

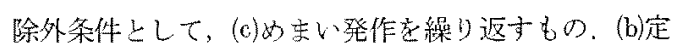
型的突発性難聴. (c)頻繁に発作変動を繰り返すものは除 外した。

[刘象〕1967年から1975年の9年間に岩手医大耳县科外 来で扱った感音難㯖のらち，2 年越し以上観察し得た症

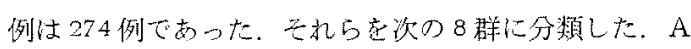

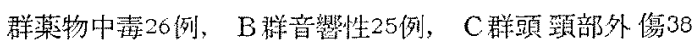
例，D群メニエール病执上びその周辺疾患39例， E群先 天性または家族性14例，F群原因不明116例， G 群他疾 患に合併したもの8例，H群後迷路性 8 例である。この 中で明らかな難婹の進行を認为たものは，A群 4 例15.4 $\% \mathrm{C}$ 群 5 例 $13.2 \%$, E群 3 例 $21.4 \%, \mathrm{~F}$ 群 4 例 $3.4 \% \%$, G 群 1 例12.5\%. H群1 例12.5\%の計18例6.6\%であっ t.

[成績]：“特難”は，E，F群の 7 例11耳で，E，F群

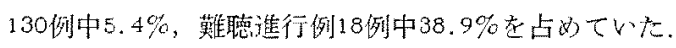

年代別に友る上，10才未溯から80代まで，20代，50代 索除き各1例ずつの代らつき走し，各年代化出現する 可能性があった。

E. F群について観察期間別の出現率をみると，1年 以内 56 例中 1 例 $1.8 \%, 1 \sim 2$ 年 43 例中 1 例 $2.3 \%, 2 \sim$ 3 年15例中 1 例 $6.7 \%, 3 \sim 5$ 年 11 例门 2 例 $18.2 \%, 5$ 年 以上 5 例中 2 例 $40 \%$ 上，锶察期間が長くなるにしたが い，出現摔が高くなっている．特に 3 年以上ではその傾 向が著明である。
7 例11耳について難聴の淮行のし方みると，一つの 音城のみの柽、進行 ( 4 耳), 低音部での著しい進行 ( 3 耳), 高音部での著し、進行 (4耳)の3つにタイプに

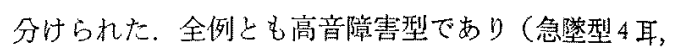
渐傾型 7 耳)，6例 $85.7 \%$ は詨称性であった，進行後の 変化は，急壁型は同型であったが，漸傾型は同型 2 耳, 急整型 7 耳, 水平型 1 耳, ピーク型 1 耳と, 䇐々な変化 芫示していた。

钼察期間別に悪化程度をみると，䘽察期間が長くなる に従い scale out が多くなり，惡化程度怔強くなってい た，しかし，中には長期間の観察であっても，埾度の琹 化例もみられた。このことは，これらが長い観察期間中 にひきつづきゆっくり変化しているといらよりはむし

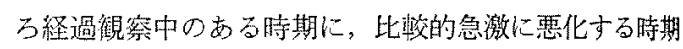
があって，それ学把えるた的には長期間の観察が必要で あるといらことを示唆していると考えられた。

[結果]：特発性两側性感音難㯖の䠄床的特徴は次の点 である。

(1)出現率は 5. 4\%でめり，観察期間が長くなるに徒い 出現渗は大となる。(2)各年代層に出現する可能性があ る. (3)両倒対称性高音障害型にみられる。(4)長期間の定 期的観察が必要である。

質問 山崎可大 (東歯大)，ワッセルマン反応が反覆 誘発法で漱く(十とでて，昔，マフラルブールクールをや り進行が止った例をる例ばかり経験している。梅毒との 関保计調べたか。

芯答 河掮 筧 今回の“特難”に関しては，梅毒の 症例はない，刘象例に注W-R H 例があったが難㯖上恃 直接の関保计なかったと思ら。

質問 服部 浩 (神戸大)。感音難聴で今回調心゙た症 例の中に逆に聪力改善例はどれ位あったか。

応答 河鴆 䓍 各音域の平均が $15 \mathrm{~dB}$ 以上という意 味だ，改善例は，15dB 以上ではないしかし，5dB と いら小さな变化で，20\%位南ったと思う。

(B 80-1049-23582)

\section{0. 感音難聴児両親の聴力検查成績}

○佐藤護人・立木桨・村井盛子・太田宏子・篦田广ナ子（岩手医大）

1. 緒言：感音難㯖小児の原因を個々の例について検

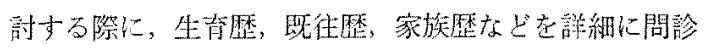

しても，ビうしても原因が判明しない例が少からず存在 する。本研究はこれらの原因不明例の原因を究明する一 